\title{
Insecticidal Activity, Growth Inhibitory and Biochemical Effects of Plant Lectins and Bacillus thuringiensis var. kurstaki against the Pink Bollworm, Pectinophora gossypiella
}

\author{
Dalia A. El-Deeb ${ }^{1}$
}

\begin{abstract}
Insecticidal activity and sublethal effects of white kidney bean and soybean lectins compared to Bacillus thuringiensis var. kurstaki were evaluated against pink bollworm (PBW), Pectinophora gossypiella (Saunders). The in vivo effects of these lectins on the total proteases and $\alpha$ amylase activities of PBW were also carried out. Results revealed that, $B$. thuringiensis $\left(\mathrm{LC}_{50}=61.7\right.$ and $36.1 \mu \mathrm{g} / \mathrm{g}$ diet) was approximately 4.7 and 4.8 times more toxic than kidney bean lectins $\left(\mathrm{LC}_{50}=\mathbf{2 8 9 . 2}\right.$ and $175.0 \mu \mathrm{g} / \mathrm{g}$ diet $)$ and 2.2 times more toxic than soybean lectins $\left(\mathrm{LC}_{50}=134.3\right.$ and $81.2 \mu \mathrm{g} / \mathrm{g}$ diet) after 5 and 6 days of treatment on the $2^{\text {nd }}$ instar larvae. The $L_{25}$ equivalent concentration of $B$. thuringiensis and soybean lectins achieved the highest reduction of larval weight $(11.9$ and $13.0 \mathrm{mg} /$ larva compared to $27.1 \mathrm{mg} /$ larva in control) after 9 days of treatment. While kidney bean and soybean lectins at $\mathrm{LC}_{10}$ and $\mathrm{LC}_{25}$ increased the average time to pupation of PBW, $B$. thuringiensis at $\mathrm{LC}_{25}$ decreased the average time to pupation compared to control. All treatments significantly decreased the pupal mean weight and adult emergence rates compared to control. Kidney bean lectins, soybean lectins and $B$. thuringiensis at $\mathrm{LC}_{25}$ reduced the average number of eggs laid / female (fecundity) to 35.2, 31.5 and 34.5, respectively, compared to 89.0 in control. In addition, \% egg hatch (fertility) significantly decreased to 53.8, 51.7 and $49.1 \%$ in kidney bean lectins, soybean lectins and $B$. thuringiensis $\mathrm{LC}_{25}$ treatments compared to $93.0 \%$ in control. Kidney bean and soybean lectins inhibited the activity of total proteases and $\alpha$-amylase. Results of the present study suggest that kidney bean and soybean lectins can be used as suitable alternatives for $B$. thuringiensis in integrated management programs of pink bollworm.
\end{abstract}

Keywords: Pink bollworm; Plant lectins; Bacillus thuringiensis; sublethal effects.

\section{INTRODUCTION}

Pink bollworm (PBW), Pectinophora gossypiella (Saunders), is a major pest of cotton in Egypt and worldwide. Larvae burrow into cotton bolls to feed on the seeds, cause serious boll damage resulting in great yield losses (Gutierrez et al, 2006; El-Aswad and Aly, 2007; Muhammad, 2017). The qualitatively and quantitatively cotton production depends mainly on the efficient control of PBW. The control of PBW relies mainly on chemical control (El-Feel et al., 1993; Khan et al., 2007; Magdy et al., 2009; El-Deeb et al., 2017) and recently Bacillus thuringiensis-transgenic cotton (Vaek et al., 1987; Mohan et al., 2016). However, chemical control is still adopted as the major tool for combating this serious insect pest.

The harmful effects of insecticides on the beneficial organisms, mammals and environment have been documented. In addition, the development of resistant strains of PBW against most of the commonly used insecticide groups (Mohamady, 2017) and Bt-transgenic cotton (Tabashnik et al., 2009; Liu et al., 2010) leads to the continuing need for new effective and economical insecticides for PBW management (Sexton et al., 2007). During the last years a lot of attention was made in the study of entomotoxic proteins called plant lectins and their insecticidal properties (Chen, 2008; Vishwanathreddy et al., 2014; Mohsen et al., 2020) .

Plant lectins are a class of proteins of non-immune origin which used as a defense tool against pathogens which attack plants (Peumans and Van Damme, 1995). Lectins are carbohydrate-binding proteins, ubiquitous in nature, have been found to be promising against homopteran (Chakraborti et al., 2009; Saha et al., 2006), lepidopteran (Macedo et al., 2007; Mohsen et al., 2020), and coleopteran insects (Vandenborre et al., 2011). Lectins are survival in the digestive system of herbivores under a wide range of $\mathrm{pH}$ that gives them a strong insecticidal potential (Vandenborre et al., 2011). They act as anti-nutritive and/or toxic substances by binding to membrane glycosyl groups lining the digestive tract, leading to an array of harmful systemic reactions (Stoger et al., 1999). Disruption of lipid, carbohydrate, and protein metabolism has negative effects on growth and development of insects (Dutta $e t$ al., 2005).

Many plant and fungal lectins have been used as a part of integrated pest management systems for many agricultural pests. Lectins have been demonstrated to affect the insect survival, development and fecundity (Carlini and Grossi-de-Sá, 2002). 
In the present study, the insecticidal activity of white kidney bean and soybean lectins and Bacillus thuringiensis var. kurstaki against PBW was evaluated. The sublethal effects of these lectins on some biological parameters were also examined. The in vivo effects of lectins on the total proteases and $\alpha$-amylase activities of PBW were also studied.

\section{MATERIALS AND METHODS}

\section{Tested insect:}

A laboratory strain of PBW was obtained from Plant Protection Research Institute, Cairo, Egypt and reared for several generations in the laboratory under conditions of $26 \pm 2{ }^{\circ} \mathrm{C}$ and $75 \pm 5 \mathrm{RH}$ as described by Rashad and Ammar (1985).

\section{Tested B. thuringiensis:}

Bacillus thuringiensis var. kuristaki as an active ingredient $\left(1 \times 10^{7}\right.$ spore $\left./ \mathrm{mg}\right)$ was obtained from Organic for Biotechnology Company, Nubaria City, Egypt.

\section{Extraction of lectins from kidney bean and soybean seeds:}

Tested lectins were extracted from kidney bean and soybean seeds as described by Varrot et al., (2013). Seed coats of kidney bean and soybean seeds were removed, $100 \mathrm{~g}$ of uncoated seeds were taken and soaked in phosphate buffer saline for $24 \mathrm{hrs}$. The uncoated seeds were grinded with a minimum volume of phosphate buffer saline and centrifuged at $5000 \mathrm{rpm}$ for $10 \mathrm{~min}$ and the supernatant was used for lectins extraction. The supernatant was fractionally precipitated with ammonium sulfate at $60 \%$ saturation and centrifuged again. The pellets were dissolved in a minimal volume of water and dialyzed in glass distilled water at $4^{\circ} \mathrm{C}$, and then lyophilized. Hemagglutinating activity test was used for detection of lectins in the extracted samples. Hemagglutination was performed on microtiter plate with the extracted lectins from white kidney bean and soybean using blood groups $\mathrm{O}$. The hemagglutination happens when the lectins bind to carbohydrate from erythrocyte surface (Varrot et al., 2013).

\section{Bioassay and determination of sublethal concentrations:}

A series of concentrations of lectin products and $B$. thuringiensis were prepared in water and mixed with the semi artificial diet (Rashad and Ammar, 1985). For each treatment, 30 newly molted $2^{\text {nd }}$ instar larvae were divided on 15 glass cups ( $28 \mathrm{ml}$ capacity). Each glass cup was provided by $5 \mathrm{~g}$ agar based PBW semi-artificial diet mixed with the tested lectins or B. thuringiensis. Control received semi-artificial diet only. Cups were covered with lids and maintained at $26 \pm 2{ }^{\circ} \mathrm{C}$. Cups were examined for larval mortality after 5 and 6 days of treatment and the larval mortality percentages were calculated. Mortality percentages were corrected according to Abbott equation (Abbott, 1925) and subjected to probit analysis (Finney, 1971). The $\mathrm{LC}_{50}$, $\mathrm{LC}_{25}$ and $\mathrm{LC}_{10}$ concentrations, confidence limits and the slopes were calculated.

Sublethal effects of tested lectins and $B$. thuringiensis on some biological parameters of pink bollworm:

The semi- artificial diet was mixed with the determined $\mathrm{LC}_{10}$ and $\mathrm{LC}_{25}$ equivalent concentrations for tested lectins and $B$. thuringiensis. Eighty $2^{\text {nd }}$ instar larvae in 4 replicates ( 2 larvae in each tube; 10 tubes per replicate) were used in each treatment and provided with the treated diet. Larvae were observed daily for pupation and emergence. Larval, pupal and adult durations were determined. Also, larval and pupal weights and percentages of adult emergence were recorded. Adults were sexed and placed in glass cups provided with a folded sheet paper as oviposition site. Two adult males were kept with one adult female to maximize the probability of successful mating. Laid eggs were counted and followed until hatching. The sublethal effects of tested lectins and $B$. thuringiensis on fecundity (total number of eggs / female) and fertility (hatchability percentages of eggs) were determined. Initially, 12 mating were planned for each insecticide treatment as well as control. The mating cups were checked daily and eggs were removed until female death. The total number of eggs /female for each mating and hatched eggs percentages were evaluated.

Effect of tested lectins and $B$. thuringiensis on the total proteases activity:

Newly molted $2^{\text {nd }}$ instar larvae were fed diet containing the $\mathrm{LC}_{25}$ and $\mathrm{LC}_{10}$ equivalent concentrations of kidney bean lectins, soybean lectins and $B$. thuringiensis and surviving larvae after 6 days were collected. Untreated larvae were used as control. One gram of total larvae was homogenized in $5 \mathrm{ml} 100 \mathrm{mM}$ Tris- $\mathrm{HCl}$ buffer $\mathrm{pH} 7$ using Polytron Kinemetica on ice. The homogenate was centrifuged at $4000 \mathrm{rpm}$ for 15 min at $4^{\circ} \mathrm{C}$ using IEC-CRU 5000 cooling centrifuge. The supernatant was used for total proteolytic activity estimation. Total proteolytic activity was measured using asocasein as a substrate according to (Olga et al., 2002; Mohen and Gujar, 2003). The homogenate was incubated in a total volume $60 \mu \mathrm{l}$ of assay buffer (100 $\mathrm{mM}$ Tris- $\mathrm{HCl} \mathrm{pH} \mathrm{8)} \mathrm{for} 20 \mathrm{~min}$ at $37^{\circ} \mathrm{C}$ before addition of $200 \mu \mathrm{l}$ of $2 \%$ azocasein (w/v in assay buffer). The reaction was allowed to proceed for $180 \mathrm{~min}$ at $37^{\circ} \mathrm{C}$, and then stopped by addition of $300 \mu \mathrm{l}$ cold $10 \%$ trichloroacetic acid (TCA). The reaction mixture was centrifuged at $3000 \mathrm{rpm}$ for $10 \mathrm{~min}$ IEC-CRU 5000 cooling centrifuge. Excess acidity was neutralized by 
adding $10 \mu \mathrm{l} \mathrm{NaOH}(10 \mathrm{~N})$ to the reaction mixture and absorbance was measured at $440 \mathrm{~nm}$ using SequoiaTurner Model 340 spectrophotometer. An assay mixture without enzyme was used as the blank.

Effect of tested lectins and $B$. thuringiensis on the amylase activity:

Surviving larvae after 6 days of treatment with $\mathrm{LC}_{25}$ and $\mathrm{LC}_{10}$ equivalent concentrations of kidney bean lectins, soybean lectins and $B$. thuringiensis were collected. Untreated larvae were used as control. One gram of total larvae was homogenized in $5 \mathrm{ml}$ glass distilled water using Polytron Kinemetica on ice. The homogenate was centrifuged at $15000 \mathrm{rpm}$ for $15 \mathrm{~min}$ at $4^{\circ} \mathrm{C}$ using IEC-CRU 5000 cooling centrifuge. The supernatant was used for $\alpha$-amylase activity assay. Alpha-amylase activity was assayed by the dinitrosalicilic acid (DNS) according to Bernfeld, (1955), using 1\% soluble starch solution as substrate. An assay mixture without enzyme was used as the blank. One unit of $\alpha$-amylase activity was defined as the amount of enzyme required to produce $1 \mathrm{mg}$ maltose in $30 \mathrm{~min}$ at $35^{\circ} \mathrm{C}$.

\section{Protein measurements:}

Lowry et al. (1951) method was used to determine protein content in the supernatant comparing to the standard curve of BSA.

\section{Statistical analysis:}

Estimates of $\mathrm{LC}_{50}$ and their $95 \%$ confidence limits were obtained using the POLO program (Russell et al., 1977) based on Finney (1971). The criterion used to estimate the differences between $\mathrm{LC}_{50}$ values was nonoverlap of their $95 \%$ confidence intervals. All other quantitative estimations were replicated four times and the values are expressed as mean \pm standard error. The SAS 8.0 software was used for analysis of the data obtained from each experiment and the means were tested for significant differences using analysis of variance (ANOVA) test (LSD at $\mathrm{P}<0.05$ ) (SAS Statistical software, 1999).

\section{RESULTS}

Toxicity of tested lectins and $\boldsymbol{B}$. thuringiensis against pink bollworm larvae:

The median lethal concentration, $\mathrm{LC}_{10}, \mathrm{LC}_{25}$ and their confidence limits of tested lectins and $B$. thuringiensis against the $2^{\text {nd }}$ instar larvae of pink bollworm are presented in Table 1. Bacillus thuringiensis $\left(\mathrm{LC}_{50}=61.7\right.$ and $36.1 \mu \mathrm{g} / \mathrm{g}$ diet $)$ was approximately 4.7 and 4.8 times more toxic than kidney bean lectins $\left(\mathrm{LC}_{50}=289.2\right.$ and $175.0 \mu \mathrm{g} / \mathrm{g}$ diet $)$ after 5 and 6 days of treatment, respectively. Bacillus thuringiensis was approximately 2.2 times more toxic than soybean lectins ( $\mathrm{LC}_{50}=134.3$ and $81.2 \mu \mathrm{g} / \mathrm{g}$ diet) after 5 and 6 days of treatment, respectively. Soybean lectins was approximately 2.2 times more toxic than kidney bean lectins after 5 and 6 days of treatment, respectively. The $\mathrm{LC}_{10}$ and $\mathrm{LC}_{25}$ values after 6 days of treatment were 4.9 and $12.6 \mu \mathrm{g} / \mathrm{g}$ diet for $B$. thuringiensis, 13.0 and $31.0 \mu \mathrm{g} / \mathrm{g}$ diet for soybean lectins, and 31.6 and $71.1 \mu \mathrm{g} / \mathrm{g}$ diet for kidney bean lectins (Table 1).

Table 1. Toxicity of kidney bean lectins, soybean lectins and $B$. thuringiensis against $2^{\text {nd }}$ instar larvae of pink bollworm

\begin{tabular}{|c|c|c|c|c|c|}
\hline Treatment & $\begin{array}{c}\text { Time after exposure } \\
\text { (days) }\end{array}$ & $\begin{array}{c}\text { LC }_{50} \\
(\mu \mathrm{g} / \mathrm{g} \text { diet }) \\
(95 \% \mathrm{CL})\end{array}$ & $\begin{array}{c}\mathrm{LC}_{25} \\
(\mu \mathrm{g} / \mathrm{g} \text { diet }) \\
(95 \% \mathrm{CL})\end{array}$ & $\begin{array}{c}\mathrm{LC}_{10} \\
(\mu \mathrm{g} / \mathrm{g} \text { diet }) \\
(95 \% \mathrm{CL})\end{array}$ & Slope \pm SE \\
\hline \multirow[t]{2}{*}{ Kidney bean lectins } & 5 & $\begin{array}{c}289.2 \\
(240.0-353.2)\end{array}$ & $\begin{array}{c}101.6 \\
(77.0-126.5)\end{array}$ & $\begin{array}{c}39.6 \\
(25.3-54.9)\end{array}$ & $1.49 \pm 0.14$ \\
\hline & 6 & $\begin{array}{c}175.0 \\
(147.7-205.8)\end{array}$ & $\begin{array}{c}71.1 \\
(54.0-88.0)\end{array}$ & $\begin{array}{c}31.6 \\
(20.8-43.0)\end{array}$ & $1.73 \pm 0.15$ \\
\hline \multirow[t]{2}{*}{ Soybean lectins } & 5 & $\begin{array}{c}134.3 \\
(112.1-163.1)\end{array}$ & $\begin{array}{c}48.7 \\
(37.1-60.2)\end{array}$ & $\begin{array}{c}19.5 \\
(12.6-26.9)\end{array}$ & $1.53 \pm 0.14$ \\
\hline & 6 & $\begin{array}{c}81.2 \\
(67.7-96.5) \\
\end{array}$ & $\begin{array}{c}31.0 \\
(22.8-39.2) \\
\end{array}$ & $\begin{array}{c}13.0 \\
(8.1-18.3) \\
\end{array}$ & $1.61 \pm 0.15$ \\
\hline \multirow[t]{2}{*}{ B. thuringiensis } & 5 & $\begin{array}{c}61.7 \\
(50.9-75.8)\end{array}$ & $\begin{array}{c}20.6 \\
(15.1-26.1)\end{array}$ & $\begin{array}{c}7.7 \\
(4.6-11.1)\end{array}$ & $1.42 \pm 0.14$ \\
\hline & 6 & $\begin{array}{c}36.1 \\
(29.5-43.5) \\
\end{array}$ & $\begin{array}{c}12.6 \\
(8.8-16.4) \\
\end{array}$ & $\begin{array}{c}4.9 \\
(2.8-7.2) \\
\end{array}$ & $1.47 \pm 0.14$ \\
\hline
\end{tabular}


Sublethal effects of tested lectins and $B$. thuringiensis on some biological parameters of pink bollworm:

Sublethal effects of tested lectins and $B$. thuringiensis on some biological parameters of pink bollworm are presented in Tables 2, 3 and 4. All treatments significantly decreased the average weight of treated pink bollworm larvae compared to control after 6 and 9 days of treatment. B. thuringiensis and soybean lectins at $\mathrm{LC}_{25}$ (12.6 and $31.0 \mathrm{mg} / \mathrm{g}$ diet) achieved the highest reduction of larval weight where the larval weight averages were 11.9 and $13.0 \mathrm{mg} /$ larva compared to $27.1 \mathrm{mg} /$ larva in control after 9 days of treatment. The larval weight averages were $17.8,17.5$ and $18.3 \mathrm{mg} /$ larva when larvae were treated with $\mathrm{LC}_{10}$ of $B$. thuringiensis, soybean lectins and kidney bean lectins after 9 days of treatment, respectively (Table 2).

Moreover, kidney bean and soybean lectins at $\mathrm{LC}_{10}$ and $\mathrm{LC}_{25}$ increased the average time to pupation of pink bollworm. However, B. thuringiensis at $\mathrm{LC}_{25}$ decreased the average time to pupation compared to control. These times were 17.7 and 19.5 days for kidney bean lectins and 18.0 and 20.1 days for soybean lectins at $\mathrm{LC}_{10}$ and
$\mathrm{LC}_{25}$, respectively, compared to 13.5 days in control. On the other hand, $B$. thuringiensis at $\mathrm{LC}_{25}$ reduced the time to pupation of pink bollworm to 11.3 days (Table 2). Sublethal concentrations of tested lectins and $B$. thuringiensis had a considerable effect on pupation percentage of pink bollworm. Kidney bean and soybean lectins at $\mathrm{LC}_{25}$ gave the lowest pupation percentages 34.7 and $37.2 \%$ compared to $93.4 \%$ in control. Also, significant decrease in pupation percentage was achieved with the $\mathrm{LC}_{10}$ of tested lectins and $B$. thuringiensis at $\mathrm{LC}_{10}$ and $\mathrm{LC}_{25}$ (Table 2).

As shown in Table 3, all treatments significantly reduced the pupal mean weight compared to control treatment. Soybean lectins and B. thuringiensis at $\mathrm{LC}_{25}$ were the most effective where the pupal mean weight was 14.5 and $13.2 \mathrm{mg} /$ pupa compared to $27.2 \mathrm{mg} /$ pupa in control. Kidney bean lectins, soybean lectins and $B$. thuringiensis at $\mathrm{LC}_{10}$ achieved less effect with pupal weight averages $19.3,18.7$ and $17.8 \mathrm{mg} / \mathrm{pupa}$, respectively. However, pupal duration did not changed significantly in all treatments compared to control (Table 3).

Table 2. Effect of kidney bean lectins, soybean lectins and $B$. thuringiensis when applied to the $2^{\text {nd }}$ instar larvae of pink bollworm on the larval weight, larval duration and \% pupation

\begin{tabular}{|c|c|c|c|c|c|c|}
\hline \multirow[t]{2}{*}{ Treatment } & \multirow[t]{2}{*}{$\begin{array}{c}\text { Conc*. } \\
\text { ( } \mu \mathrm{g} / \mathrm{g} \text { diet) }\end{array}$} & \multicolumn{3}{|c|}{$\begin{array}{c}\text { Mean weight }(\mathrm{mg} / \mathrm{larva})( \pm \mathrm{SE}) \text { after } \\
\text { different days of treatment }\end{array}$} & \multirow{2}{*}{$\begin{array}{c}\text { Larval } \\
\text { duration } \\
\text { (days) } \pm \mathrm{SE}\end{array}$} & \multirow[t]{2}{*}{$\begin{array}{l}\text { Pupation } \\
(\%) \pm \text { SE }\end{array}$} \\
\hline & & 3 & 6 & 9 & & \\
\hline Control & - & $6.7 \pm 0.5 \mathrm{a}$ & $18.4 \pm 1.1 \mathrm{a}$ & $27.1 \pm 1.5 \mathrm{a}$ & $13.5 \pm 1.2 \mathrm{c}$ & $93.4 \pm 4.2 \mathrm{a}$ \\
\hline \multirow[t]{2}{*}{ Kidney bean lectins } & 31.6 & $4.9 \pm 0.6 \mathrm{ab}$ & $13.4 \pm 1.0 \mathrm{~b}$ & $18.3 \pm 0.8 b$ & $17.7 \pm 0.7 b$ & $63.2 \pm 2.5 c$ \\
\hline & 71.1 & $4.3 \pm 0.3 b$ & $10.5 \pm 0.6 c$ & $14.5 \pm 0.7 \mathrm{c}$ & $19.5 \pm 1.5 \mathrm{a}$ & $34.7 \pm 2.3 \mathrm{e}$ \\
\hline \multirow{2}{*}{ Soybean lectins } & 13.0 & $5.0 \pm 0.4 \mathrm{ab}$ & $14.2 \pm 0.7 b$ & $17.5 \pm 0.9 b$ & $18.0 \pm 1.6 b$ & $69.1 \pm 3.7 b$ \\
\hline & 31.0 & $4.7 \pm 0.2 \mathrm{ab}$ & $10.3 \pm 0.3 c$ & $13.0 \pm 0.8 \mathrm{~cd}$ & $20.1 \pm 0.8 \mathrm{a}$ & $37.2 \pm 1.9 \mathrm{e}$ \\
\hline \multirow[t]{2}{*}{ B. thuringiensis } & 4.9 & $5.2 \pm 0.6 \mathrm{ab}$ & $13.2 \pm 0.3 b$ & $17.8 \pm 0.5 b$ & $13.1 \pm 0.5 \mathrm{c}$ & $68.1 \pm 2.4 b$ \\
\hline & 12.6 & $4.9 \pm 0.2 \mathrm{ab}$ & $9.8 \pm 0.4 c$ & $11.9 \pm 0.7 \mathrm{~d}$ & $11.3 \pm 1.8 \mathrm{~d}$ & $44.8 \pm 2.5 \mathrm{~d}$ \\
\hline
\end{tabular}

*These concentrations are equivalent to the $\mathrm{LC}_{10}$ and $\mathrm{LC}_{25}$ of tested lectins and B. thuringiensis. Within a column, means possessing the same letter do not differ significantly at $P=0.05$.

Table 3. Effect of kidney bean lectins, soybean lectins and $B$. thuringiensis when applied to the $2^{\text {nd }}$ instar larvae of pink bollworm on the pupal weight, pupal duration and \%adult emergence

\begin{tabular}{lcccc}
\hline Treatment & $\begin{array}{c}\text { Conc*. } \\
(\boldsymbol{\mu g} / \mathbf{g} \text { diet })\end{array}$ & $\begin{array}{c}\text { Pupal mean weight } \\
(\mathbf{m g} / \mathbf{p u p a}) \pm \mathbf{S E}\end{array}$ & $\begin{array}{c}\text { Pupal duration } \\
(\mathbf{d a y s}) \pm \mathbf{S E}\end{array}$ & $\begin{array}{c}\text { \%Adult emergence } \\
\pm \text { SE }\end{array}$ \\
\hline Control & - & $27.2 \pm 1.4 \mathrm{a}$ & $6.4 \pm 0.5 \mathrm{a}$ & $91.0 \pm 3.5 \mathrm{a}$ \\
Kidney bean lectins & 31.6 & $19.3 \pm 0.9 \mathrm{~b}$ & $7.3 \pm 0.4 \mathrm{a}$ & $55.4 \pm 2.1 \mathrm{~b}$ \\
& 71.1 & $15.4 \pm 0.6 \mathrm{c}$ & $6.9 \pm 0.3 \mathrm{a}$ & $37.2 \pm 1.5 \mathrm{~d}$ \\
Soybean lectins & 13.0 & $18.7 \pm 0.5 \mathrm{~b}$ & $7.0 \pm 0.4 \mathrm{a}$ & $46.3 \pm 2.1 \mathrm{c}$ \\
& 31.0 & $14.5 \pm 0.4 \mathrm{~cd}$ & $6.7 \pm 0.5 \mathrm{a}$ & $29.4 \pm 1.7 \mathrm{e}$ \\
B. thuringiensis & 4.9 & $17.8 \pm 0.3 \mathrm{~b}$ & $6.8 \pm 0.3 \mathrm{a}$ & $53.2 \pm 2.4 \mathrm{~b}$ \\
& 12.6 & $13.2 \pm 0.6 \mathrm{~d}$ & $6.3 \pm 0.2 \mathrm{a}$ & $30.1 \pm 1.4 \mathrm{e}$ \\
\hline
\end{tabular}

*These concentrations are equivalent to the $\mathrm{LC}_{10}$ and $\mathrm{LC}_{25}$ of tested lectins and $B$. thuringiensis. Within a column, means possessing the same letter do not differ significantly at $P=0.05$. 
Reduction in adult emergence rates were significantly achieved by all treatments. Soybean lectins and $B$. thuringiensis at $\mathrm{LC}_{25}$ achieved the higher reduction in the adult emergence rates, where it was 29.4 and $30.1 \%$, respectively, compared to $91.0 \%$ in control. The adult emergence rate was 55.4 and $53.2 \%$ at the $\mathrm{LC}_{10}$ kidney bean lectins and $B$. thuringiensis treatments, respectively (Table 3).

Effect of kidney bean lectins, soybean lectins and $B$. thuringiensis when applied on the $2^{\text {nd }}$ instar larvae of pink bollworm on adult fecundity, fertility and longevity is presented in Table 4. Kidney bean lectins, soybean lectins and $B$. thuringiensis at $\mathrm{LC}_{25}$ had the highest effect on the adult fecundity where the average number of eggs laid / female were 35.2, 31.5 and 34.5, respectively, compared to 89.0 in control. Also, tested lectins and $B$. thuringiensis at the $\mathrm{LC}_{10}$ significantly decreased the adult fecundity where the average number of eggs laid / female were 58.7, 57.4 and 56.6, respectively. Fertility (percentages of egg hatch) was significantly decreased as a result of all treatments. The $\mathrm{LC}_{25}$ values of all treatments were the most effective compared to the $\mathrm{LC}_{10}$ values. The \% egg hatch was $53.8,51.7$ and $49.1 \%$ in kidney bean lectins, soybean lectins and $B$. thuringiensis $\mathrm{LC}_{25}$ treatments compared to $93.0 \%$ in control. Adult longevity was significantly decreased to 7.1 and 6.2 days in $\mathrm{LC}_{10}$ and $\mathrm{LC}_{25}$ kidney bean lectins treatments, 6.8 and 6.4 days in $\mathrm{LC}_{10}$ and $\mathrm{LC}_{25}$ soybean lectins treatments and 7.2 and 6.8 days in $\mathrm{LC}_{10}$ and $\mathrm{LC}_{25}$ B. thuringiensis treatments compared to 9.5 days in control (Table 4).

Effect of kidney bean lectins, soybean lectins and $B$. thuringiensis on the pink bollworm total proteases and $\alpha$-amylase activity:

The specific activity of total proteases $\left(\mathrm{OD}_{440} / \mathrm{mg}\right.$ protein / hr) in pink bollworm $2^{\text {nd }}$ instar larvae after 6 days of treatment with $\mathrm{LC}_{10}$ and $\mathrm{LC}_{25}$ of kidney bean and soybean lectins is significantly decreased compared to control (Table 5). The highest enzyme activity inhibition was occurred by kidney bean and soybean lectins at $\mathrm{LC}_{25}$, where the inhibition percentage was 54.0 and $51.6 \%$, respectively.

Table 4. Effect of kidney bean lectins, soybean lectins and $B$. thuringiensis when applied to the $2^{\text {nd }}$ instar larvae of pink bollworm on adult fecundity, fertility and longevity

\begin{tabular}{lcccc}
\hline Treatment & $\begin{array}{c}\text { Conc*. } \\
(\boldsymbol{\mu g} / \mathbf{g} \text { diet })\end{array}$ & $\begin{array}{c}\text { Fecundity } \\
\text { (No. eggs laid / female) } \\
\mathbf{\pm S E}\end{array}$ & $\begin{array}{c}\text { fertility } \\
(\boldsymbol{\%} \text { egg hatch) } \\
\mathbf{\pm S E}\end{array}$ & $\begin{array}{c}\text { Adult longevity } \\
\text { (days) } \pm \mathbf{S E}\end{array}$ \\
\hline Control & - & $89.0 \pm 2.5 \mathrm{a}$ & $93.0 \pm 3.1 \mathrm{a}$ & $9.5 \pm 0.3 \mathrm{a}$ \\
Kidney bean lectins & 31.6 & $58.7 \pm 2.2 \mathrm{~b}$ & $62.5 \pm 3.5 \mathrm{~b}$ & $7.1 \pm 0.2 \mathrm{~b}$ \\
& 71.1 & $35.2 \pm 1.5 \mathrm{c}$ & $53.8 \pm 2.2 \mathrm{c}$ & $6.2 \pm 0.4 \mathrm{~b}$ \\
Soybean lectins & 13.0 & $57.4 \pm 2.1 \mathrm{~b}$ & $64.6 \pm 3.8 \mathrm{~b}$ & $6.8 \pm 0.5 \mathrm{~b}$ \\
& 31.0 & $31.5 \pm 1.9 \mathrm{c}$ & $51.7 \pm 2.6 \mathrm{c}$ & $6.4 \pm 0.2 \mathrm{~b}$ \\
B. thuringiensis & 4.9 & $56.6 \pm 2.7 \mathrm{~b}$ & $66.4 \pm 2.9 \mathrm{~b}$ & $7.2 \pm 0.5 \mathrm{~b}$ \\
& 12.6 & $34.5 \pm 1.3 \mathrm{c}$ & $49.1 \pm 1.2 \mathrm{c}$ & $6.8 \pm 0.3 \mathrm{~b}$ \\
\hline
\end{tabular}

*These concentrations are equivalent to the $\mathrm{LC}_{10}$ and $\mathrm{LC}_{25}$ of tested lectins and $B$. thuringiensis. Within a column, means possessing the same letter do not differ significantly at $P=0.05$.

Table 5. In vivo effect of kidney bean lectins, soybean lectins and $B$. thuringiensis on the $2^{\text {nd }}$ instar larvae of pink bollworm total proteases activity after 6 days of treatment

\begin{tabular}{lcccc}
\hline Treatment & $\begin{array}{c}\text { Conc*. } \\
(\boldsymbol{\mu g} / \mathbf{g} \text { diet })\end{array}$ & $\begin{array}{c}\text { Specific activity } \\
(\mathbf{O D} \mathbf{4 4 0} / \mathbf{m g} \text { protein/hr) } \mathbf{E S E}\end{array}$ & $\begin{array}{c}\text { Activity } \\
(\boldsymbol{\%} \text { control })\end{array}$ & \% Inhibition \\
\hline Control & - & $0.213 \pm 0.004 \mathrm{a}$ & $100 \pm 1.9$ & 0.0 \\
Kidney bean lectins & 31.6 & $0.127 \pm 0.003 \mathrm{c}$ & $59.6 \pm 1.4$ & 40.4 \\
& 71.1 & $0.098 \pm 0.004 \mathrm{~d}$ & $46.0 \pm 1.9$ & 54.0 \\
Soybean lectins & 13.0 & $0.149 \pm 0.006 \mathrm{~b}$ & $70.0 \pm 2.8$ & 30.0 \\
& 31.0 & $0.103 \pm 0.004 \mathrm{~d}$ & $48.4 \pm 1.9$ & 51.6 \\
B. thuringiensis & 4.9 & $0.203 \pm 0.007 \mathrm{a}$ & $95.3 \pm 3.3$ & 4.7 \\
& 12.6 & $0.205 \pm 0.003 \mathrm{a}$ & $96.2 \pm 1.4$ & 3.8 \\
\hline
\end{tabular}

*These concentrations are equivalent to the $\mathrm{LC}_{10}$ and $\mathrm{LC}_{25}$ of tested lectins and $B$. thuringiensis. Within a column, means possessing the same letter do not differ significantly at $P=0.05$. 
On the other hand, total proteases activity did not differ significantly in $B$. thuringiensis treatments compared to control (Table 5). In addition, tested lectins and $B$. thuringiensis at $\mathrm{LC}_{10}$ and $\mathrm{LC}_{25}$ exhibited remarkable inhibitory effect on $\alpha$-amylase enzyme activity of pink bollworm larvae (Table 6). Kidney bean lectins at $\mathrm{LC}_{10}$ and $\mathrm{LC}_{25}$ (achieved 55.9 and $61.9 \%$ inhibition) was significantly the most effective inhibitor of $\alpha$-amylase activity, followed by soybean lectins and $B$. thuringiensis (Table 6).

\section{DISCUSSION}

The production of cotton fibers depends mainly upon the efficient control of pink bollworm because it is the most destructive insect pests infested cotton. The evolution of resistance in this insect to insecticides (Kristensen, 2005; Mohamady, 2017) and B. thuringiensis transgenic cotton (Dhurua and Gujar, 2011; Wang et al., 2016; Akhtar et al., 2018) requires the use of different strategies for management of this insect. In the present study toxicity of lectins from kidney bean and soybean compared to B. thuringiensis against pink bollworm larvae were tested. Results revealed that, Bacillus thuringiensis is more toxic than soybean lectins which is more toxic than kidney bean lectins. Lectins from different sources exerted an insecticidal activity against many phytophagous insects such as caterpillars, tobacco hornworm, cotton leaf worm and beetles (Vandenborre et al., 2011). Sadeghi et al., (2009) reported a significant larval mortality of $S$. littoralis fed on the transgenic plants expressing Allium porrum L. lectins. In addition, soybean and kidney been lectins achieved high mortality of the $2^{\text {nd }}$ instar larvae of S. littoralis (Mohsen et al., 2020).
Annona coriacea lectins showed high insecticidal activity against Anagast kuehniella and Corcyra cephalonica larvae when it was incorporated into an artificial diet (Coelho et al., 2007). Both the heterodimeric and homodimeric garlic lectins exhibited high mortality when fed to pea aphids in artificial diet (Fitches et al., 2008). Sá et al., (2009) and Napoleão et al., (2012) recorded a high insecticidal activity of lectins isolated from Myracrodruon urundeuva bark, heartwood and Myracrodruon urundeuva against Aedes aegypti larvae. Furthermore, Sclerotium rolfsii lectins showed a remarkable mortality rate of Spodoptera litura larvae (Vishwanathreddy et al., 2014).

Results of the present study also revealed that, kidney bean lectins, soybean lectins and $B$. thuringiensis significantly decreased the average weight of pink bollworm larvae and pupae. In addition, the percent pupation, adult emergence, fecundity and fertility were significantly suppressed in pink bollworm larvae fed diet contains kidney bean lectins, soybean lectins and $B$. thuringiensis. In previous studies, bioassays using detached leaves from transgenic tobacco plants expressing the Allium porrum L. lectins reduced the weight gain of $2^{\text {nd }}$ instar larvae of $S$. littoralis. In addition the lectins retarded the development of the larvae and metamorphosis, reduced pupal weight and increased mortality rate (Sadeghi et al., 2009). Mohsen et al., (2020) also reported a significant decrease in the S. littoralis larval and pupal weights, percent pupation, adult emergence, fecundity and fertility. Similarly, snowdrop lectin affected the growth and development of beet armyworm, Spodoptera exigua (Naghdi and Bandani, 2013), while it reduced survival, biomass and caused longer instar durations in Lacanobia oleracea (Fitches et al., 1997; Wakefield et al., 2006).

Table 6. In vivo effect of kidney bean lectins, soybean lectins and $B$. thuringiensis on the $2^{\text {nd }}$ instar larvae of pink bollworm $\alpha$-amylase activity after 6 days of treatment

\begin{tabular}{lcccc}
\hline Treatment & $\begin{array}{c}\text { Conc*. }(\boldsymbol{\mu g} / \mathbf{g} \\
\mathbf{d i e t})\end{array}$ & $\begin{array}{c}\text { Specific activity } \\
(\boldsymbol{\mu m o l} \text { maltose/min/mg protein) } \pm \mathbf{S E}\end{array}$ & $\begin{array}{c}\text { Activity } \\
(\boldsymbol{\%} \text { control) }\end{array}$ & $\begin{array}{c}\text { \% } \\
\text { Inhibition }\end{array}$ \\
\hline Control & - & $1.37 \pm 0.03 \mathrm{a}$ & $100 \pm 2.2$ & 0.0 \\
Kidney bean lectins & 31.6 & $0.604 \pm 0.02 \mathrm{e}$ & $44.1 \pm 1.5$ & 55.9 \\
& 71.1 & $0.522 \pm 0.02 \mathrm{~g}$ & $38.1 \pm 1.5$ & 61.9 \\
Soybean lectins & 13.0 & $0.798 \pm 0.01 \mathrm{~d}$ & $58.2 \pm 0.7$ & 41.8 \\
& 31.0 & $0.582 \pm 0.02 \mathrm{f}$ & $42.5 \pm 1.5$ & 57.5 \\
B. thuringiensis & 4.9 & $0.945 \pm 0.03 \mathrm{~b}$ & $69.0 \pm 2.2$ & 31.0 \\
& 12.6 & $0.872 \pm 0.01 \mathrm{c}$ & $63.6 \pm 0.7$ & 36.4 \\
\hline
\end{tabular}

*These concentrations are equivalent to the $\mathrm{LC}_{10}$ and $\mathrm{LC}_{25}$ of tested lectins and B. thuringiensis. Within a column, means possessing the same letter do not differ significantly at $P=0.05$. 
The remarkable inhibitory effects of kidney bean and soybean lectins on total proteases and $\alpha$-amylase activities of pink bollworm larvae in the present study also explain their negative effects on the growth parameters. Plant lectins may be interact with glycosylated moieties or other regions of the enzyme molecules (Agra-Neto et al., 2014). It is documented that, many plant lectins have been shown to interact with $\alpha$-amylase (Santos et al., 2020), $\alpha$-and $\beta$ glucosidases (Lagarda-Diaz et al., 2017) and trypsinlike enzymes (Oliveira et al., 2020).

Histological analysis of lectin-treated midgut revealed disrupted and diffused secretory cells surrounding the gut lumen in larvae of Hyblaea puera and Probergrothius sanguinolens. The damage noticed in the gut of both insects suggests the interference of lectins with the secretory layer of the gut lumen, thereby revealing that this lectins probably affected the insect secretory mechanism and hampered food uptake in larvae of the tested insect pests (George et al., 2018). Findings in the present study suggest that kidney bean and soybean lectins might be suitable protein for integrating into plant genomes for the controlling pink bollworm.

\section{REFERENCES}

Abbott, W.S. 1925. A method of computing the effectiveness of an insecticide. Econ. Entomol. 18: 265-267.

Agra-Neto, A.C., T.H. Napoleão, E.V. Pontual, N.D. Santos, A. Luz, C.M.F. de Oliveira, M.A.V. de Melo-Santos, L.C.P. Coelho, D.M. Navarro and P.M.G. Paiva. 2014. Effect of Moringa oleifera lectins on survival and enzyme activities of Aedes aegypti larvae susceptible and resistant to organophosphate. Parasitol. Res. 113: 175-184.

Akhtar, Z.R., Z. Saeed, A. Noreen, A. Jabeen, E.H. Hira, A. Ihsan and S. Ullah. 2018. Pink bollworm showing genetic resistance against cry1Ac expressing transgenic cotton. J. Entomol. and Zool. Stud. 6: 2711-2715.

Bernfeld, P. 1955. Amylases, $\alpha$ and $\beta$. Methods in Enzymology. 1: 149-158.

Carlini, C.R. and M.F. Grossi-de-Sá. 2002. Plant toxic proteins with insecticidal properties. A review on their potentialities as bioinsecticides. Toxicon. 40: 1515-1539.

Chakraborti D, A. Sarkar, H.A. Mondal and S. Das. 2009. Tissue specific expression of potent insecticidal, Allium sativum leaf agglutinin (ASAL) in important pulse crop, chickpea (Cicer arietinum L.) to resist the phloem feeding Aphis craccivora. Transgenic Res. 18:529-44.

Chen, M.S. 2008. Inducible direct plant defense against insect herbivores: A review. Insect Sci. 15: 101-114.
Coelho, M.B., S. Marangoni and M.L. Macedo. 2007. Insecticidal action of Annona coriacea lectin against the flour moth Anagast kuehniella and the rice moth Corcyra cephalonica (Lepidoptera: Pyralidae). Copparative Biochemistry and Physiology - Part C: Toxicology and Pharmacology. 146: 406 - 414.

Dhurua, S. and G.T. Gujar. 2011. Field-evolved resistance to Bt toxin Cry1Ac in the pink bollworm, Pectinophora gossypiella (Saunders) (Lepidoptera: Gelechiidae), from India. Pest Manag. Sci. 67: 898-903.

Dutta I., P. Saha, P. Majumder, A. Sarkar, D. Chakraborti and S. Banerjee. 2005. The efficacy of a novel insecticidal protein, Allium sativum leaf lectin (ASAL), against homopteran insects monitored in transgenic tobacco. Plant Biotechnol. J. 3: 601-11.

El-Aswad, A.F. and M.I. Aly. 2007. Screening of some insecticides against the cotton bollworms, Pectinophora gossypilla (Saund.) and Earias insulana (Boisd.). J. Pest Cont. Environ. Sci. 15: 63-74.

El-Deeb, D.A., M.H.A. Metayi, D.A. Awad and A.F. Bedair. 2017. Field evaluation of selected insecticide sequences against two cotton bollworms with reference to side effects on Coccinella undecimpunctata L. J. Plant Prot. and Path., Mansoura Univ. 8: 305 - 309.

El-Feel, E.A., A.E.M. El-Sorady, H.A. Awad and M.E. Omar. 1993. Influence of certain insecticide regimes against bollworms and other cotton pests and their predators. Alex. Sci. Exch. 14: 145-165.

Finney, D.J. 1971. Probit analysis, Cambridge Univ. Press, Cambridge.

Fitches, E., D. Wiles, A.E. Douglas, G. Hinchliffe, N. Audsley and J.A. Gatehouse. 2008. The insecticidal activity of recombinant garlic lectins towards aphids. Insect Biochemistry and Molecular Biology. 38: 905 - 915.

Fitches, E.C., A.M.R. Gatehouse and J.A. Gatehouse. 1997. Effects of snowdrop lectin (GNA) delivered via artificial diet and transgenic plants on the development of tomato moth (Lacanobia oleracea) larvae in laboratory and glasshouse trials. Journal of Insect Physiology. 43: 727739.

George, B.S., S. Silambarasan, K. Senthil, J.P. Jacob and M.G. Dasgupta. 2018. Characterization of an insecticidal protein from Withania somnifera against lepidopteran and hemipteran pest. Molecular Biotechnology. 60: 290-301.

Gutierrez, A.P., T. D’Oultremont, C.K. Ellis and L. Ponti. 2006. Climatic limits of pink bollworm in Arizona and California: effects of climate warming. Acta Oecologica. 30: $353-364$.

Khan, R.R., S. Ahmed, M.W. Saleem and M. Nadeem. 2007. Field evaluation of different insecticides against spotted bollworms Erias spp. at district sahiwal. Pakistan Entomologist. 29: 129 - 133.

Kristensen, M. 2005. Glutathione $S$-transferase and insecticide resistance in laboratory strains and field populations of Musca domestica. J. Econ. Entomol. 98: 1341-1348. 
Lagarda-Diaz, I., A.M. Guzman-Partida and L. VazquezMoreno. 2017. Legume lectins: proteins with diverse applications. Int. J. Mol. Sci. 18: 1242.

Liu, F., Z. Xu, Y.C. Zhu, F. Huang, Y. Wang, W. Zhou and J. Shen. 2010. Evidence of field evolved resistance to Cry1Ac expressing Bt cotton in Helicoverpa armigera in northern China. Pest Manag. Sci. 66:155-161.

Lowery, O.H., N.J. Rosenbourgh and R.J. FarrRondall. 1951. Protein measurement with folin phenol reagent. J. Biol. Chem. 193: 265-275.

Macedo M.L., M.D.G.M. Freire, M.B. Da Silva and L.C. Coelho. 2007. Insecticidal action of Bauhinia monandra leaf lectin (BmoLL) against Anagasta kuehniella (Lepidoptera: Pyralidae), Zabrotes subfasciatus and Callosobruchus maculates (Coleoptera: Bruchidae). Comp. Biochem. Physiol. Mol. Integr. Physiol. 146: 48698.

Magdy, A.Z., M.M. Ibrahim, M.M. shekeban and H.M. Ebed. 2009. Effect of three insecticides and two insecticides alternatives on pink bollworm, Pectinophora gossypilla and quality of cotton yield. Alex. Univ. J. Agric. Res. 54: 155-163.

Mohamady, A. H. 2017. Monitoring of insecticides resistance level and biochemical changes in two field populations of pink bollworm, Pectinophora gossypiella (Saunders). J. Biol. Chem. Research. 34: 510-522.

Mohan, K.S., K.C. Ravi, P.J. Suresh, D. Sumerford and G.P. Head. 2016. Field resistance to the Bacillus thuringiensis protein Cry1Ac expressed in Bollgard ${ }^{\circledR}$ hybrid cotton in pink bollworm, Pectinophora gossypiella (Saunders), populations in India. Pest Manag Sci. 72: 738 - 46.

Mohen, M. and T. Gujar. 2003. Characterization and comparison of midgut proteases of Bacillus thuringiensis susceptible and resistant diamondback moth (Lepidoptera: Plutellidae). J. Invertebr. Pathol. 82: 1-11.

Mohsen, S.F.E., M.A. Abbassy, H.K. Abou-Taleb and E.I. Rabea. 2020. Plant-lectins as insecticidal agents against cotton leafworm Spodoptera littoralis and their potential applications in crop protection. The Natural Products J. 10: $1-14$

Muhammad, S. 2017. Biological parameters of pink Bollworm, Pectinophora gossypiella (Saunders) (Lepidoptera: Gelechiidae): a looming threat for cotton and its eradication opportunity. International J. Research in Agriculture and Forestry. 4: 25 - 36.

Naghdi, M. and A.R. Bandani. 2013. The effect of GNA lectin on the $\alpha$-amylase activity of the beet armyworm, Spodoptera exigua Hb. (Lepidoptera: Noctuidae). Arch. Phytopathol. and Plant Protec. 46: 1270-1277.

Napoleao, T.H., E.V. Pontual, T.A. Lima, N.D.L. Santos, R.A. Sa, L.C.B. Coelho, D.N.A. Vavarro and P.M.G. Paiva. 2012. Effect of Myracrodruon urundeuva leaf lectin on survival and digestive enzymes of Aedes egypti larvae. Parasitology Research. 10: 2529 - 2537.
Olga, L., M.M. Ibrahim, N.C. Candas, N.C. Koller, L.S. Bauer and L.A. Bulla. 2002. Changes in proteases activity and Cry 3Aa toxin binding in the Colorado potato beetle: implications for insect resistance to Bacillus thuringiensis toxins. Insect Biochem. Mol. Biol. 32: 567-5.

Oliveira, C.T., S.W. Machado, C.D.S. Bezerra, M.H. Cardoso, O.L. Franco, C.P. Silva, D.G. Alves, C. Rios and M.L.R. Macedo. 2020. Effects of a reserve protein on Spodoptera frugiperda development: A biochemical and molecular approach to the entomotoxic mechanism. Molecules. 25: 2195.

Peumans, W.J. and E.J.M. Van Damme. 1995. Lectins as plant defense proteins. Plant Physiol. 109: 347-352.

Rashad, A.M. and E.D. Ammar. 1985. Mass rearing of the spiny bollworm, Earias insulana (Boisd.) on semiartificial diet. Bull. Soc. Ent. Egypte. 65: 239 - 242.

Russell, R.M., J.L. Robertson and N.E. Savin. 1977. POLO: a new computer program for Probit analysis. Bulletin of the Entomological Society of America. 23: 209-213.

Sa, R.A., N.D. de Lima Santos, C.S.B. da Silva, T.H. Napoleao, F.S. Gomes, B.S. Cavada and P.M.G. Paiva. 2009. Larvicidal activity of lectins from Myracrodruon urundeuva on Aedes aegypti. Copparative Biochemistry and Physiology - Part C: Toxicology and Pharmacology. 149: $300-306$.

Sadeghi, A., G. Smagghe, E. Jurado-Jacome, W.J. Peumans and J.M. Van Damme. 2009. Laboratory study of the effects of leek lectin (APA) in transgenic tobacco plants on the development of cotton leafworm Spodoptera littoralis (Lepidoptera: Noctuidae). Eur. J. Entomol. 106: 21-28.

Saha P., P. Majumder, I. Dutta, T. Ray, S.C. Roy and S. Das. 2006. Transgenic rice expressing Allium sativum leaf lectin with enhanced resistance against sap-sucking insect pests. Planta. 223: 1329-43.

Santos, N.D.L., T.H. Napoleão, C.A. Benevides, L.P. Albuquerque, E.V. Pontual, A.P.S. Oliveira and P.M.G. Paiva. 2020. Effect of gamma irradiation of Moringa oleifera seed lectin on its larvicidal, ovicidal, and oviposition-stimulant activities against Aedes aegypti. S. Afr. J. Bot. 129: 3-8.

SAS Institute, Inc. 1999. PC-SAS users guide, Version 8. North Carolina statistical analysis system Institute, Inc.

Sexton, S.E., Z. Lei and D. Zilberman. 2007. The Economics of Pesticides and Pest Control. International Review of Environmental and Resource Economics. 1: 271-326.

Stoger E., S. William, P. Christou, R.E. Down and J.A. Gatehouse. 1999. Expression of the insecticidal lectin from snowdrop (Galanthus nivalis agglutinin; GNA) in transgenic wheat plants: effects on predation by the grain aphid Sitobion avenae. Mol. Breed. 5: 65-73.

Tabashnik, B.E., J.B.J. Van Rensburg and Y. Carrière. 2009. Field-evolved insect resistance to Bt crops: definition, theory and data. J. Econ. Entomol. 102: 2011-2025.

Vaek, M., A. Reynaerts and A. Hofte. 1987. Transgenic plants protected from insects. Nature. 325: $33-37$. 
Vandenborre G., G. Smagghe, and E.J.M. Van Damme. 2011. Plant lectins as defense proteins against phytophagous insects. Phytochemistry. 72:1538-1550.

Vandenborre, G., G. Smagghe, E.J. Van Damme. 2011. Plant lectins as defense proteins against phytophagous insects. Phytochemistry. 72: 1538-1550.

Varrot, A., S.M. Basheer and A. Imberty. 2013. Fungal lectins: structure, function and potential applications. Curr. Opin. Struct. Biol. 23: 678-685.

Vishwanathreddy, H., G.G. Bhat, S.R. Inamdar, R.K. Gudihal, B.M. Swamy. 2014. Sclerotium rolfsii lectin exerts insecticidal activity on Spodoptera litura larvae by binding to membrane proteins of midgut epithelial cells and triggering caspase-3-dependent apoptosis. Toxicon. 78: 47-57.
Wakefield, M.E., H.A. Bell, E.C. Fitches, J.P. Edwards and A.M. Gatehouse. 2006. Effects of Galanthus nivalis agglutinin (GNA) expressed in tomato leaves on larvae of the tomato moth Lacanobia oleracea (Lepidoptera: Noctuidae) and the effect of GNA on the development of the endoparasitoid Meteorus gyrator (Hymenoptera: Braconidae). Bulletin of Entomological Research. 96: 4352.

Wang, L., P. Wan, S. Cong, J. Wang, M. Huang, B.E. Tabashnik, X. Li, and K. Wu. 2016. Adult exposure to Bt toxin Cry1Ac reduces life span and reproduction of resistant and susceptible pink bollworm (Lepidoptera: Gelechiidae). J. Econ. Entomol. 109: 1357-1363. 


\section{الملخص العربي}

\section{النشاط الإبادى على الحشرات والتأثيرات المثبطة للنمو والتأثيرات البيوكيميائية للكتينات النباتية وبكتيريا الباسيلس ثيورينجينزز ضد دودة اللوز القرنفلية}

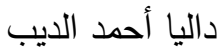

من المعاملة. بينما اللكتينات المستخلصة من الفاصوليا البيضاء وفول الصويا أدت إلى زيادة الوقت اللازم لتحول اليرقات إلى عذارى لدودة اللوز القرنفلية فإن بكتيريا الباسيلس البلاء ثيورينجينزز أدت إلى خفض هذا الوقت. كل المعاملات

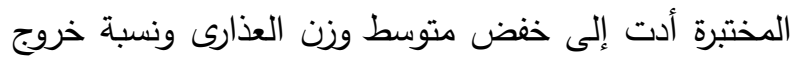

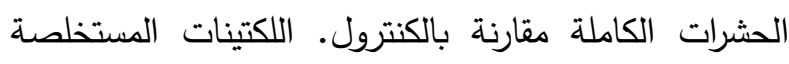
من الفاصوليا البيضاء وفول الصويا وبكتيريا الباسيلس

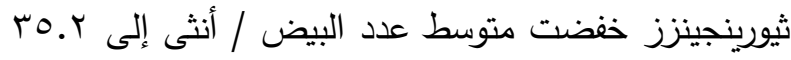

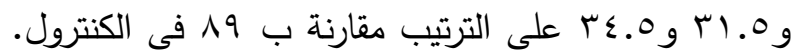

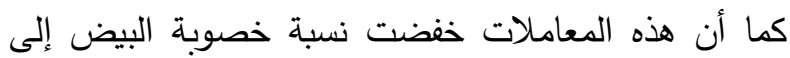

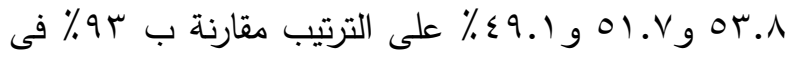

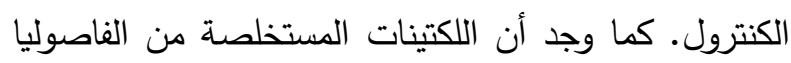

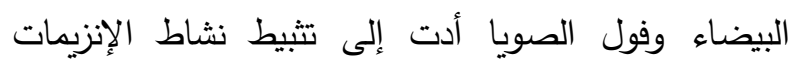

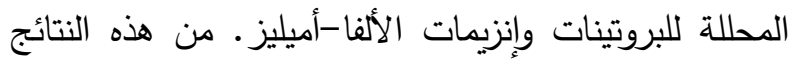
يمكن القول أن اللكتينات المستخلصة من الفاصوليا البيضاء

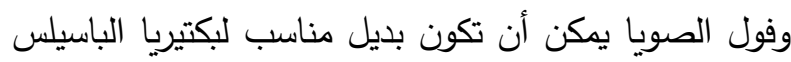

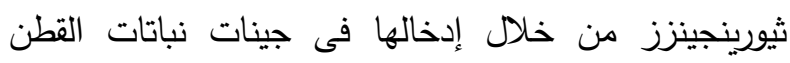
ل المكافحة دودة اللوز القرنغلية.
تم دراسة السمية الحشرية والتأثيرات التحت مميتة للكتينات المستخلصة من الفاصوليا البيضاء وفول الصويا مقارنة بكتيريا الباسيلس ثيورينجينزز على دودة اللوز

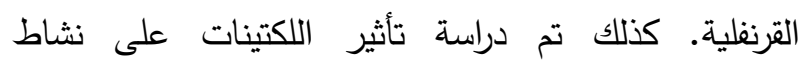

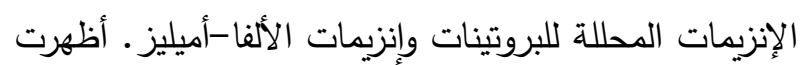
النتائج أن سمية بكتيريا الباسيلس ثيورينجينزز (التركيز اللازم التيات

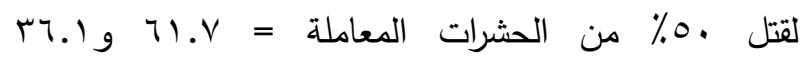

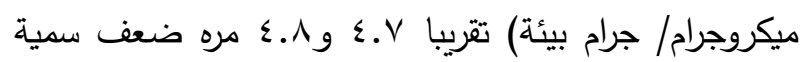
اللكتين المستخلص من الفاصوليا البيضاء (التركيز اللازم

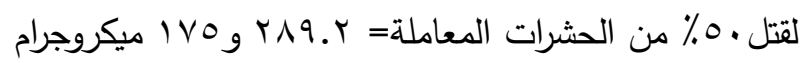

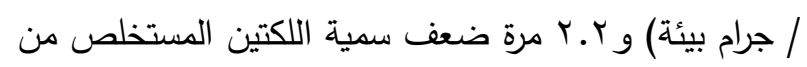

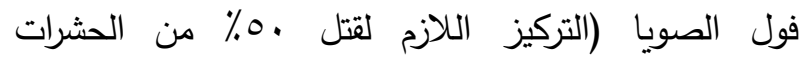

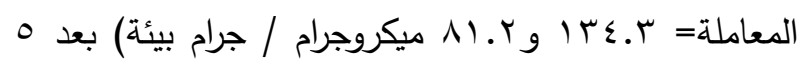

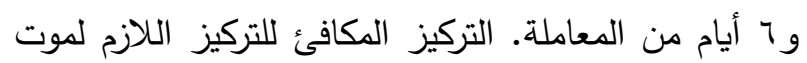

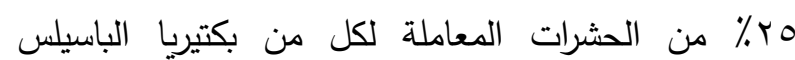

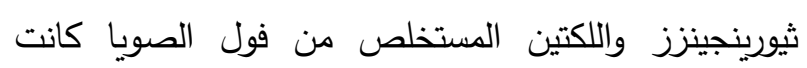

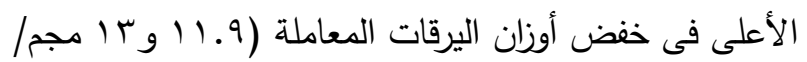

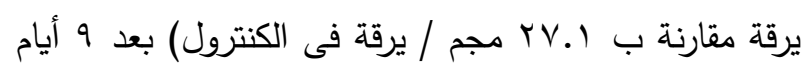

